\title{
PROCEDURES FOR THE SETTLEMENT OF DISPUTES BETWEEN MILITARY ORDERS IN THE TWELFTH AND THIRTEENTH CENTURIES
}

Middle Ages; Military Orders; arbitration; transfers; property disputes; co-operation

目 isputes between military orders in the twelfth and thirteenth centuries could hardly be avoided. It is not surprising that, as the possessions of the orders grew, rights over property became the most frequent source of conflict. Yet there were also other causes of discord: assaults by individual brothers, transfers from one order to another, the design of habits ${ }^{1}$ and obligations of mutual hospitality could all occasion disputes. Claims by one order to authority over another, such as those of the Hospital over the Teutonic Order and of the Temple and Calatrava over the order known first as Mountjoy and then as Monfragüe ${ }^{2}$, were a further source of dissension. Arrangements were needed to prevent or settle differences, especially as military orders - particularly the Templars and Hospitallers - were increasingly criticized for their disputes and rivalries.

In some instances, attempts were made to eliminate conflict by regulating relationships between orders. Rules were, for example, drawn up to check attempted transfers from one order to another. The Templar customs allude to an agreement with the Hospital which prevented brothers of one order from entering the other ${ }^{3}$, and texts of several rulings made by military orders in the Iberian Peninsula on

1 On clashes between the Templars and the Teutonic order on this issue, see N. E. Morton, The Teutonic Knights in the Holy Land, 1190-1291, Woodbridge 2009, p. 57.

2 A summary of the dispute between the Hospital and the Teutonic order is provided by Morton (as n. 1), pp. 91-95; on the Temple, Calatrava and Mountjoy/Monfragüe, see A. J. Forey, The Order of Mountjoy, Speculum 46 (1971), pp. 259-264.

3 La règle du Temple, ed. H. de Curzon, Paris 1886, art. 429, p. 233; Il Corpus normativo templare. Edizione dei testi romanzi con traduzione e commento in italiano, ed. G. Amatuccio, Galatina 2009, art. 124, pp. 218-220. 
this issue survive. An agreement between Calatrava and Santiago in 1188 decreed that a brother of one order should not transfer to the other without his master's consent $t^{4}$, and the necessity of consent was also mentioned in another agreement between these orders in $1243^{5}$, while forty years later the prior of the Hospital in Castile and Leon and the master of Santiago similarly agreed that there should be no transfers between their orders without a written licence from the relevant master or prior, unless a brother had been expelled from his original order. This last agreement was occasioned by the fact that brothers had not only been transferring but also taking horses, arms and other goods with them to their new order. ${ }^{6}$ Such regulations did not in fact altogether prevent transfers between military orders, even though these were not always to a stricter order; nor did they define any particular procedures which were to be followed if unlawful transfers were attempted. Issues relating to transfers from one military order to another were in practice often referred to the pope. ${ }^{7}$

Procedures were, however, sometimes devised to deal with instances when a brother of one order had been ill-treated by a member of another. In 1178 in the kingdom of Leon the Temple, Hospital and Santiago agreed that in these circumstances the accused was to be judged by the chapter of the complainant. ${ }^{8}$ In an agreement between Santiago and Calatrava in the first decade of the thirteenth century it was ruled that any brother who was shown to have a grudge against members of the other order was to do penance for a year, during which, if he was a knight, he was to be deprived of horse, arms and office. Officials of Santiago who were negligent in providing hospitality to brothers of Calatrava were to walk barefoot to Maqueda or Zorita, which belonged to Calatrava, while offenders of

4 Bullarium ordinis militiae de Calatrava, ed. I. J. de Ortega y Cotes, F. Alvarez de Baquedano, P. de Ortega Zúñiga y Aranda, Madrid 1761, pp. 25-26; Bullarium equestris ordinis S. Iacobi de Spatha, ed. A. F. Aguado de Córdova, A. A. Alemán y Rosales, J. López Agurleta, Madrid 1719, p. 42; J. L. Martín, Origenes de la orden militar de Santiago (1170-1195), Barcelona 1974, doc. 240, pp. 416-417.

5 Bullarium de Calatrava (as n. 4), p. 685.

6 Libro de privilegios de la orden de San Juan de Jerusalén en Castilla y León (siglos XII-XV), ed. C. de Ayala Martínez, Madrid 1995, doc. 364, pp. 586-588. On relations between Santiago and the Hospitallers, see J. V. Matellanes Merchán, Relaciones entre las órdenes de San Juan y Santiago en Castilla y León en los siglos XII y XIII, in: Actas del primer simposio histórico de la orden de San Juan en España, Toledo 2003, pp. 93-98.

7 See, for example, A. J. Forey, Desertions and Transfers from Military Orders (Twelfth to EarlyFourteenth Centuries), Traditio 60 (2005), pp. 177, 192.

8 Bullarium S. Iacobi (as n. 4), p. 20; Martín (as n. 4), doc. 92, pp. 272-273; S. García Larragueta, La orden de San Juan en la crisis del imperio hispánico del siglo XII, Hispania 12 (1952), doc. 20, pp. 516-517. 
Calatrava were to trek to Uclés, which was under the lordship of Santiago. ${ }^{9}$ Similar provisions regarding hospitality were included in a pact made between the same two orders in $1221 .{ }^{10}$ Procedures to be followed when a member of one order assaulted a brother of another were also included in an agreement between the three leading orders in the Holy Land in 1258: on receipt of a request from the preceptor of the complainant, the defendant was to be judged by the statutes of his own order and was to be sent to another district according to the wishes of the preceptor who had raised the matter. ${ }^{11}$ Four years later, in a document relating to the Aragonese lordships of Castellote and Alcañiz, officials of the Temple and Calatrava ruled that if a brother or vassal of one lordship wronged someone in the other either by committing a crime or in the matter of debts or of contracts, the preceptor of the accused was to do justice. It was also ruled that brothers and their vassals in one lordship should not distrain those of the other. ${ }^{12}$ Nothing, however, is known of the implementation of such decrees.

More commonly, attempts were made by military orders to establish permanent arrangements for arbitration in disputes about lands and rights over property, although these procedures could also be used in some other circumstances. In the Iberian Peninsula Santiago, the Hospital and the Temple in the kingdom of Leon did this in 1178, as did Santiago and Calatrava ten years later and in $1221 .{ }^{13}$ In 1224 these two orders, together with the Templars and Hospitallers in Castile and Leon, agreed further procedures for arbitration. ${ }^{14}$ In 1237 the Hospital and Santiago made a more local provision about future disputes relating to the lordships of Consuegra and Uclés in Castile, and local agreements were also made in 1239 between Santiago and Calatrava, and in 1283 between Santiago and the Hospitallers in Castile and Leon. ${ }^{15}$ In the East the masters of the Temple and Hospital had, at

9 J. F. O'Callaghan, Hermandades between the Military Orders of Calatrava and Santiago during the Castilian Reconquest, 1158-1252, Speculum 44 (1969), pp. 616-617, appendix 1.

10 Bullarium de Calatrava (as n. 4), pp. 683-684.

11 J. Delaville Le Roulx, Cartulaire général de l’ordre des Hospitaliers de Saint-Jean de Jérusalem, 4 vols, Paris 1894-1906, here vol. 2, doc. 2902, pp. 859-863; E. Strehlke, Tabulae ordinis theutonici, Berlin 1869, doc. 116, pp. 98-103.

12 El cartulario de la encomienda templaria de Castellote (Teruel), 1184-1283, ed. S. de la Torre Gonzalo, Zaragoza 2009, doc. 9, pp. 80-81.

13 Bullarium S. Iacobi (as n. 4), pp. 20, 42; Bullarium de Calatrava (as n. 4), pp. 25-26, 683-684; Martín (as n. 4), docs 92, 240, pp. 272-273, 416-417; García Larragueta (as n. 8), doc. 20, pp. 516-517.

14 O’Callaghan (as n. 9), pp. 617-618, appendix 2.

15 D. W. Lomax, La orden de Santiago (1170-1275), Madrid 1965, doc. 24, pp. 257-262; Libro de privilegios (as n. 6), docs 267, 364, pp. 465-470, 586-588; Bullarium de Calatrava (as n. 4), pp. 686-688; M. Rivera Garretas, La encomienda, el priorato y la villa de Uclés en la edad media (1174-1310), Madrid-Barcelona 1985, doc. 172, pp. 375-377. 
the behest of Alexander III, entered into an agreement in 1179 for settling disputes between the two orders in all parts of western Christendom ${ }^{16}$, and in 1258 the three leading orders in the Holy Land agreed arrangements for arbitration regarding certain issues in the eastern Mediterranean. ${ }^{17}$

In the settlement made in 1178 between the Hospital, the Temple and Santiago, a dispute between two of these orders was to be adjudged by the third; but the usual arrangement was that differences were to be settled by a certain number of brothers chosen from the orders which had entered into a pact. In 1179 it was decreed that arbitration should be by three Templars and three Hospitallers, who were to include the head of the house or province where the dispute had occurred; if these failed to agree, friends (amici) were to be called in to help. In the last resort the masters of the two orders were to act. Nine years later Santiago and Calatrava decided that each master should choose five brothers of his order to decide disputes, and in 1221 it was ruled that the masters of these two orders should each select three brothers as arbiters. The 1224 agreement between four orders in Leon and Castile provided for the establishment of a commission of twelve brothers - three from each order - to make decisions, and in the local pact of 1237 the Hospital and Santiago agreed to submit future disputes to four commanders of each order. In the Holy Land in 1258 it was agreed that if the leading officials of the region where a dispute had arisen were unable to reach agreement, one or two brothers of each of the orders involved should be chosen to arbitrate; if they could not agree, the assistance of a member of the third order was to be invoked. Similarly, in 1283 Santiago and the Hospitallers ruled that arbitration should be by a commander from each of the orders.

Several of these agreements were later renewed or confirmed. In 1199 Innocent III reissued Alexander III's bull of 1179, which had ratified the agreement between the Temple and Hospital ${ }^{18}$, and in 1275 Gregory X, on the Hospital's petition, confirmed the arrangements made by the three orders in the Holy Land

16 R. Hiestand, Papsturkunden für Templer und Johanniter, Neue Folge, Göttingen 1984, docs 27-28, pp. 237-247; Delaville Le Roulx, Cartulaire (as n. 11), here vol. 1, doc. 558, pp. 378-379; L. Pagarolas i Sabaté, La comanda del Temple de Tortosa: primer periode (1148-1213), Tortosa 1984, doc. 69, pp. 239-241; Col.lecció diplomática de la casa del Temple de Gardeny (1070-1200), ed. R. Sarobe i Huesca, 2 vols, Barcelona 1998, here vol. 1, doc. 332, pp. 485-487; A. Ferreira, Memorias e noticias historicas da celebre ordem militar dos Templarios, 2 vols, Lisbon 1735, here vol. 2, pp. 785-788; H. E. Mayer, Die Urkunden der lateinischen Könige von Jerusalem, 4 vols, Hannover 2010, here vol. 2, doc. 407, pp. 693-697.

17 Delaville Le Roulx, Cartulaire (as n. 11), here vol. 2, doc. 2902, pp. 859-863; Strelhke (as n. 11), doc. 116, pp. 98-103.

18 Delaville Le Roulx, Cartulaire (as n. 11), here vol. 1, doc. 1068, p. 666; for Alexander III's confirmation, see ibid., here vol. 1, doc. 570, p. 387; Hiestand (as n. 16), doc. 30, pp. 248-249; 
in $1258 .{ }^{19}$ In 1243 the settlement made by Calatrava and Santiago in 1221 was renewed and amplified by the masters of the two orders, and in 1284 the general chapter of Santiago ratified the agreement made with the Hospital in the previous year. ${ }^{20}$

Yet in practice most of these provisions for arbitration appear to have been commonly ignored. Disputes between Templars and Hospitallers in the last two decades of the twelfth century were usually settled by other means than those defined in 1179. When in 1189 the Templars of Tortosa, near the mouth of the Ebro in Spain, and the neighbouring Hospitallers of Amposta had been in conflict for a long time and with animosity about certain properties and rights over water, the Aragonese King Alfonso II, acting with the archbishop of Tarragona and the bishop of Tortosa and others, imposed a settlement. ${ }^{21}$ Two years later a boundary dispute between the Templars and Hospitallers of St Gilles was submitted to two secular arbiters. ${ }^{22}$ In 1196 differences between the Templars of Novillas and the Hospitallers of Mallén in Aragon about rights to water and timber were decided by two outside arbiters, who had been nominated by the Aragonese king. ${ }^{23}$ In the closing years of the century rival claims to property by the Hospitallers of Trinquetaille and the Templars of Arles were judged by the archbishop of Arles. ${ }^{24}$ Lastly, in 1199 Innocent III stepped in to rule on a dispute about a fief in the district of Margat, in the principality of Antioch, after an arbitration by local prelates and others had not been accepted. ${ }^{25}$ The conflict had led to violence, which the

T. Rymer, Foedera, conventiones, litterae et cuiuscunque generis acta publica, 4 vols, London 1816-1869, here vol. 1, part 1, p. 44.

19 Delaville Le Roulx, Cartulaire (as n. 11), here vol. 3, doc. 3565, pp. 318-319; Strelhke (as n. 11), doc. 127, pp. 118-119; H. Prutz, ElfDeutschordens-Urkunden aus Venedig und Malta, Altpreussische Monatsschrift 20 (1883), doc. 6, p. 391.

20 Bullarium de Calatrava (as n. 4), pp. 685-686; Bullarium S. Iacobi (as n. 4), pp. 225-226; Rivera Garretas (as n. 15), doc. 230, pp. 437-438.

21 Delaville Le Roulx, Cartulaire (as n. 11), here vol. 1, doc. 873, pp. 554-555; A. I. Sánchez Casabón, Alfonso II Rey de Aragón, Conde de Barcelona y Marqués de Provenza. Documentos (1162-1196), Zaragoza 1995, doc. 495, pp. 655-658.

22 Cartulaire du prieuré de Saint-Gilles de l'Hôpital de Saint-Jean de Jérusalem (1129-1210), ed. D. Le Blévec, A. Venturini, Paris 1997, doc. 348, pp. 297-298.

23 Madrid, Archivo Histórico Nacional (henceforth: AHN), Ordenes Militares, carpeta 670, doc. 12; C. Barquero Goñi, La encomienda hospitalaria de Mallén durante la edad media (siglos XII-XIV), Borja 1996, p. 36.

24 Cartulaire de Trinquetaille, ed. P.-A. Amargier, Gap 1972, docs 172-173, pp. 159-162.

25 Delaville Le Roulx, Cartulaire (as n. 11), here vol. 1, doc. 1069, pp. 666-667; Die Register Innocenz' III, vol. 1, ed. O. Hageneder, A. Haidacher, Graz 1964, doc. 561, pp. 818-819; J. Riley-Smith, The Knights of St. John in Jerusalem and Cyprus, c. 1050-1310, London 1967, p. 444 . 
pope described as harmful to all Christendom and advantageous to the enemies of the Christian faith, and he told the orders to act in future in accordance with the 1179 agreement. ${ }^{26}$

Yet this instruction fell on deaf ears. In the early thirteenth century disputes between Templars and Hospitallers were not usually decided in accordance with that agreement. In 1200 the abbot of Poblet was appointed as arbiter on a number of issues in dispute in Aragon and Catalonia, and in the next year an altercation about property in the district of the Catalan city of Tortosa was submitted to outside mediators, including the bishop of Tortosa. ${ }^{27}$ An undated fragment of a document, probably compiled before the end of the first decade of the thirteenth century, also records that the Templar Pons Marescalci instructed the Hospitaller castellan of Amposta to do justice before the noble Raymond of Moncada about all the grievances which the Temple then had against the Hospital in the city of Tortosa. The castellan responded that he would not appear before a secular judge but would do justice according to the procedure agreed in the East - a reference to the 1179 agreement - or before an ecclesiastical judge. Pons apparently then argued that that agreement was not applicable in places under Templar jurisdiction, and asked Raymond of Moncada, who exercised authority in Tortosa under the lordship of the Templars, to compel the Hospitallers to appear before him; and this the castellan was obliged to do. ${ }^{28}$ In 1218 the Templars in Aragon and Catalonia referred several grievances against the Hospitallers to Honorius III, who nominated judges to settle the issue ${ }^{29}$, and in 1221 the bishop of Tortosa was again named as arbiter on various disputed rights in Catalonia. ${ }^{30}$ The participation of the Temple and Hospital in the agreement made in Spain in 1224 also implies that disputes between them in Leon and Castile would not be settled using the

26 It was this dispute which led Innocent to issue his confirmation of the 1179 agreement.

27 AHN, Códices, cód. 662B/495, pp. 31-33; Barcelona, Archivo de la Corona de Aragón, Ordenes religiosas y militares (henceforth: ACA, ORM), San Juan de Jerusalén, Cartulario de Tortosa (signatura 115), docs 143-144, fol. 46r-47r; Pagarolas i Sabaté (as n. 16), doc. 121, pp. 309-311.

28 ACA, ORM, San Juan de Jerusalén, Cartulario de Tortosa, doc. 145, fol. 47r-47v; cf. J. Shideler, A Medieval Catalan Noble Family: The Montcadas, 1000-1230, Berkeley 1983, p. 202. The document mentions a brother Jordan, who is also named in another charter relating to Tortosa drawn up in 1207 and in this Pons Marescalci is given the title of commander of Monzón and lieutenant of the Templar provincial master: Pagarolas i Sabaté (as n. 16), doc. 128, pp. 321-323; A. Virgili, Diplomatari de la catedral de Tortosa (1193-1212). Episcopat de Gombau de Santa Oliva, Barcelona 2001, pp. 343-345.

29 D. Mansilla, La documentación pontificia de Honorio III (1216-1227), Rome 1965, doc. 166, p. 130.

30 Delaville Le Roulx, Cartulaire (as n. 11), here vol. 2, doc. 1721, pp. 289-290. 
procedures agreed in 1179. In the next year, however, it was stated that the Aragonese provincial master of the Temple and the Hospitaller castellan of Amposta did make an agreement on the authority of the masters of the two orders according to the method solemnly and jointly agreed between them and long observed for settling disputes and conflicts by selecting brothers from each party. Yet two brothers from each side, rather than the three specified in 1179 , were chosen as arbiters, and one issue was left to the judgement of the bishop of Tortosa. ${ }^{31}$ In 1231 a boundary dispute in Aragon between the Templar convent of Ambel and the Hospitaller house of Añon was submitted to outside arbiters, including the justiciar of Borja. ${ }^{32}$ It has, however, been claimed that the provisions of the 1179 agreement were implemented in arbitrations between Templars and Hospitallers in Portugal in 1231 and $1239^{33}$, but this is not a necessary conclusion. On each occasion two, and not three, brothers of each order acted as arbiters, and the documents recording their decisions make no reference to the procedures defined in 1179. ${ }^{34}$

These examples are all taken from the Iberian peninsula, for which the sources are fairly extensive, but a dispute in 1209 between Templars and Hospitallers of St Gilles was also judged by two laymen ${ }^{35}$, and in the East a conflict about rights over Gibel in 1221 was referred to the pope, who committed the case to the papal legate Pelagius, and in 1233 the masters of the Temple and Hospital entrusted disputed issues to Albert, patriarch of Antioch, who acted with the counsel of three brothers of each order and other probi homines. ${ }^{36}$ Two years later Theoderic, archbishop of Ravenna and papal legate, was hearing evidence about disputed claims relating to mills and water in Acre, although later in 1235 Gregory IX wrote that his decision had been rejected and that the orders had come to blows. He asserted

31 L. Pagarolas i Sabaté, Les Templers de les terres de l'Ebre (Tortosa). De Jaume I fins a l'abolició de l'orde (1213-1312), 2 vols, Tarragona 1999, here vol. 2, doc. 24, pp. 29-31; see also ACA, ORM, San Juan de Jerusalén, pergaminos, Gardeny 510.

32 A. Bonilla y San Martín, Documentos jurídicos aragoneses del siglo XII (apuntes y documentos), in: II Congreso de historia de la Corona de Aragón, Huesca 1922, pp. 291-294, appendix D.

33 P.-V. Claverie, Lordre du Temple en Terre Sainte et à Chypre au XIIIe siècle, 3 vols, Nicosia 2005, here vol. 2, p. 203; K. Toomaspoeg, L'ordre du Temple en Occident et au Portugal, in: A extinção da ordem do Templo, ed. J. A. Carreiras, Tomar 2012, p. 39.

34 S. A. Gomes, Observações em torno das chancelarias das ordens militares em Portugal, na idade média, in: As ordens militares e as ordens de cavalaria na construção do mundo ocidental, ed. I. C. F. Fernandes, Palmela 2005, docs 4, 5, pp. 159-161. In 1231 some decisions were in fact taken by two brothers: Delaville Le Roulx, Cartulaire (as n. 11), here vol. 2, doc. 1972, pp. 413-414.

35 Cartulaire du prieuré de Saint-Gilles (as n. 22), doc. 351, p. 300.

36 Delaville Le Roulx, Cartulaire (as n. 11), here vol. 2, docs 1725, 1739, 2058, pp. 292, 297, 455-457; Riley-Smith (as n. 25), pp. 444-446. 
that over a trivial matter the Temple and Hospital were exposing what remained of the Holy Land to the infidel, and he decided to settle the dispute himself. ${ }^{37}$

The agreement made in the East in 1258 was implemented two years later, when two Hospitallers, two Templars and a brother of the Teutonic order acted as arbiters in a dispute between the Temple and the Hospital about rights in the lordship of Margat. ${ }^{38}$ That agreement, however, covered only a limited range of issues, as it excluded disputes about castles, townships and casalia; but in 1262 differences on all issues between these two orders in the Holy Land were entrusted to the arbitration of the bishop of Bethlehem, the grand commander of the Teutonic order and the constable and seneschal of the kingdom of Jerusalem. ${ }^{39}$

Procedures agreed between orders in the Iberian Peninsula for the settlement of disputes over property and rights seem to have been similarly ignored. Despite the agreement between Santiago and Calatrava in 1221, two years later Santiago appealed to the pope about rights which were disputed with the other order. ${ }^{40}$ In 1232 an altercation about boundaries between the Hospital and Santiago was admittedly referred to three brothers of each order and a Templar and a brother of Calatrava ${ }^{41}$, and this could be seen as an adaptation of the procedure agreed in 1224. Yet in the same year the Hospital and Calatrava settled another boundary dispute without reference to Santiago and the Temple ${ }^{42}$, and in 1237 the master of Calatrava was named to determine boundaries which were in dispute between Santiago and the Hospital ${ }^{43}$, while in 1233 Santiago had again turned to the pope

37 Delaville Le Roulx, Cartulaire (as n. 11), here vol. 2, docs 2107, 2120-2121, pp. 483, 489-490. The orders had, however, already agreed to a settlement by the time of the pope's intervention: ibid., here vol. 2, doc. 2117, pp. 486-487. Several disputes between the Templars and Hospitallers in the East in the late twelfth and early thirteenth centuries are known only from an eighteenth-century inventory, and details of the procedures employed have not survived: ibid., here vol. 1, doc. 1049, pp. 656-657; vol. 2, docs 1134, 1144, pp. 4, 7; J. Delaville Le Roulx, Inventaire des pièces de Terre-Sainte de l'ordre de l'Hopittal, Revue de l'orient latin 3 (1895), nos 184, 189, 190, pp. 73, 74.

38 Delaville Le Roulx, Cartulaire (as n. 11), here vol. 2, doc. 2943, p. 885.

39 Ibid., here vol. 3, docs 3026-3029, 3032, 3045, pp. 30-33, 35, 58-60; Strehlke (as n. 11), doc. 123, pp. 114-115; Mayer (as n. 16), here vol. 3, docs 812-814, 816, pp. 1416-1420, 1422-1425 .

40 Bullarium S. Iacobi (as n. 4), pp. 74-75; Mansilla (as n. 29), docs 451, 456, pp. 327-328, 329-330 .

41 Lomax (as n. 15), pp. 48-49.

42 Bullarium de Calatrava (as n. 4), pp. 64-66; Libro de privilegios (as n. 6), doc. 261, pp. 456-458; P. Guerrero Ventas, El gran priorato de Castilla y León de San Juan en el Campo de la Mancha, Toledo 1969, doc. 22, pp. 350-351.

43 Lomax (as n. 15), doc. 24, pp. 257-262; Libro de privilegios (as n. 6), doc. 267, pp. 465-470. 
when it was involved in separate disputes with the Hospitallers and the Templars. ${ }^{44}$ It may also be noted that the creation of new procedures in the Iberian Peninsula often implied that existing arrangements were not being observed.

Disputes tended to be determined by ad hoc arrangements rather than by the agreed long-term procedures. Cases were commonly decided by arbiters who were selected to judge individual disputes: these mediators varied in number and, although they were sometimes brothers of the orders involved in a dispute, they were often outsiders. Alternatively, appeals were made to the pope who then delegated local prelates to judge the issues. ${ }^{45}$

There are several possible reasons for this neglect. As has been seen, on some occasions orders appear to have had little enthusiasm for settling disputes. This was, however, not necessarily a reason for ignoring arbitration procedures in the long term: hostility and acts of violence inevitably delayed mediation but did not altogether preclude it. Yet a reluctance to settle could lead to intervention by secular rulers or the pope, who might impose their own methods of achieving a settlement, and in this way procedures agreed between orders might be ignored.

A further reason was that some procedures were cumbersome and difficult to implement. The need to assemble the twelve members of the commission established in the 1224 agreement would have taken time, and it may have been difficult to achieve a consensus within a group of that size. ${ }^{46}$ The common practice of choosing brothers from each party as arbiters could easily lead to deadlock if these tended to favour their own order, especially as brothers were usually nominated by their fellow brethren: in 1221 it was agreed that the master of Santiago should choose three brothers of Calatrava, while the master of the latter order was to select three from Santiago as arbiters, but this was unusual. ${ }^{47}$ There may obviously have been a desire to keep matters in the hands of the orders and not to entrust decisions to outsiders, which would tend to make disputes more widely

44 Bullarium S. Iacobi (as n. 4), p. 97; C. Barquero Goñi, Los Hospitalarios en el reino de León (siglos XII y XIII), El reino de León en la alta edad media 9 (1997), doc. 33, pp. 589-590; S. Domínguez Sánchez, Documentos de Gregorio IX (1227-1241) referentes a España, León 2004, docs 251, 253, pp. 237-238, 238-239.

45 On the procedures used to determine disputes between the Templars of Novillas and the Hospitallers of Mallén during the thirteenth century, for example, see Barquero Goñi, La encomienda hospitalaria de Mallén (as n. 23) pp. 37-48; A. J. Forey, A Thirteenth-Century Dispute between Templars and Hospitallers in Aragon, Durham University Journal 80 (1988), pp. 181-192; see also Lomax (as n. 15), pp. 47-49, about disputes involving the order of Santiago.

46 Lomax (as n. 15), p. 48, states that the commission of twelve is not mentioned in any later document.

47 Bullarium de Calatrava (as n. 4), pp. 683-684. In a particular dispute in Catalonia in 1225 the Hospital did, however, choose Templar brothers as arbiters, and vice versa: Pagarolas i Sabaté, Les Templers (as n. 31), here vol. 2, doc. 24, pp. 29-31. 
known, and - as has been mentioned - brothers were sometimes chosen as ad hoc arbiters, but to have members of the orders involved in disputes as arbiters was not necessarily the most effective means of reaching acceptable decisions. The 1224 agreement may also have been unpopular because it envisaged that the commission would not only determine disputes between orders but also intervene in an order's internal affairs: it was to correct the head of any order who erred or dissipated his order's possessions.

Implementation of agreements may also have been hampered by the common practice of referring groups of complaints to the pope. Both in 1223 and at the end of 1232 and the beginning of 1233 Santiago was referring to the papacy a series of disputes involving various individuals and institutions $s^{48}$, and it may have seemed convenient to include current differences with other military orders among these, even when there were procedures in place for settling such disputes.

Yet neglect of agreed procedures for settling disputes, whether about property or other matters, could also have been occasioned by ignorance. It is not always known how widely agreements were publicised, although copies of the 1179 pact between the Temple and Hospital were obviously circulated throughout the orders, for a copy survives in Lisbon and several in Catalonia, and others - now lost - are known to have existed elsewhere. ${ }^{49}$ In 1243 it was ruled that the agreement between Santiago and Calatrava should be read out at chapters of these orders, so that there could be no plea of ignorance, and similarly the terms agreed between the three leading orders in the Holy Land in 1258 included a requirement that the agreement should be read out annually at the general chapters of these orders. Newly-appointed officials of orders in the East were also to be obliged to swear to observe the pact made in $1258 . .^{50}$ In 1262 it was further ruled that the agreement then made between the Temple and Calatrava in Aragon was to be read out every month in villages near the borders of the Templar and Calatravan lordships so that men of each party may better keep and observe this pact. ${ }^{51}$ Whether such injunctions were implemented is, of course, not known. It may also be pointed out that the

48 Bullarium S. Iacobi (as n. 4), pp. 74-76, 95-98; Mansilla (as n. 29), docs 452-455, 457-459, pp. 328-329, 330-331; Domínguez Sánchez (as n. 44), docs 240-249, 256, pp. 232-237, $240-241$.

49 Hiestand (as n. 16), doc. 28, pp. 239-241; Pagarolas i Sabaté, La comanda del Temple de Tortosa (as n. 16), doc. 69, pp. 239-241; Col.lecció diplomática de Gardeny (as n. 16), here vol. 1, doc. 332, pp. 485-487; Ferreira (as n. 16), here vol. 2, pp. 785-788. Hardly any copies of the 1258 agreement have survived, but several must have been drawn up: Mayer (as n. 16), here vol. 3 , doc. 807, pp. 1409-1411.

50 Bullarium de Calatrava (as n. 4), p. 686; Delaville Le Roulx, Cartulaire (as n. 11), here vol. 2, doc. 2902, pp. 859-863; Strehlke (as n. 11), doc. 116, pp. 98-103.

51 Cartulario de Castellote (as n. 12), doc. 9, pp. 80-81. 
1179 agreement between the Temple and Hospital was copied into the cartulary which was compiled for the Templar house of Tortosa in Spain in the second half of the thirteenth century. ${ }^{52}$ But this merely implies that the agreement was among the documents in the archive of that house when the cartulary was made: it does not necessarily signify that it was then of practical significance. A similar comment could be made about the agreement between the Temple and Calatrava in 1262, which was copied into the cartulary of Castellote compiled some ten years later. ${ }^{53}$ Ignorance would, however, in many instances have been encouraged by frequent changes in the personnel of officials and a lack of literacy among knights and sergeants who held office. Terms of office of heads of houses and provinces were usually fairly short, and an ability to read Latin, in which most agreements were written, was probably not widespread among lay brothers. ${ }^{54}$ Although documents from Catalonia in the early decades of the thirteenth century indicate that the 1179 agreement between Templars and Hospitallers had not then been completely forgotten in some quarters, its terms seem to have been only vaguely recalled.

Failure to implement agreed procedures for settling disputes should not therefore be attributed solely to animosity between orders; and, although any discussion of these procedures inevitably focuses attention on disagreements and conflicts between military orders, it should be remembered that the documents recording these procedures, especially the hermandades drawn up in the Iberian Peninsula, not only sought to provide a means for settling differences but also often included provisions for collaboration and co-operation between orders on various other matters. ${ }^{55}$ Several Spanish agreements provided for joint action in warfare against the infidel: the issues covered included fighting alongside each other, sharing booty, respect for another order's truces, and arrangements for the brothers of one order to fight under the command of the master or leading official of another. ${ }^{56}$ In Spain undertakings were also given for mutual aid against aggressors. In 1178,

52 On this cartulary, see Pagarolas i Sabaté, La comanda del Temple de Tortosa (as n. 16), pp. 13-14 .

53 Cartulario de Castellote (as n. 12), pp. 18-19; A. J. Forey, Sources for the History of the Templars in Aragon, Catalonia and Valencia, Archives 21 (1994), p. 18.

54 I have sought to discuss the question of literacy in Literacy and Learning in the Military Orders during the Twelfth and Thirteenth Centuries, in: The Military Orders, vol. 2: Welfare and Warfare, ed. H. Nicholson, Aldershot 1998, pp. 185-193.

55 For surveys of some of the Spanish hermandades, see O'Callaghan (as n. 9), pp. 609-618; S. Z. Conedera, Brothers in Arms: Hermandades among the Military Orders in Medieval Iberia, in: Crusades - Medieval Worlds in Conflict, ed. T. F. Madden, J. L. Naus, V. Ryan, Farnham 2010, pp. 35-44.

56 Martín (as n. 4), doc. 92, pp. 272-273; Bullarium de Calatrava (as n. 4), pp. 683-684; O'Callaghan (as n. 9), pp. 617-618, appendix 2. 
for example, three orders pledged mutual defence of their rights, even against the king, and a century later the Temple and Calatrava agreed that, if an outsider seized goods from the lordship of either, the vassals of the other order were to assist in recovering them. ${ }^{57}$ Agreements in the East tended to be less specific, although it was ruled in 1258 that if the master of one order was absent from the East, the other two orders should undertake to protect the interests of his order while he was away. ${ }^{58}$ It may also be noted that the statement in the 1221 agreement between Santiago and Calatrava that in all things all should be seen to be brothers of one order was anticipated in the 1179 pact which commented that Templars and Hospitallers although they are of two houses by profession, should nevertheless seem to be of one. ${ }^{59} \mathrm{It}$ is in fact not difficult to find examples of co-operation and collaboration in the East ${ }^{60}$, as well as in Spain ${ }^{61}$, although in the Iberian Peninsula military orders did not enjoy the same freedom of action in military matters as they acquired in the Holy Land. Networks between orders were created, whether formally or not, even if agreements were not always fully implemented and altercations could not be prevented. The orders were like members of a family who could at times be very supportive of each other while at others engaging in protracted squabbles.

57 Bullarium S. Iacobi (as n. 4), p. 20; Martín (as n. 4), doc. 92, pp. 272-273; García Larragueta (as n. 8), doc. 20, pp. 516-517; Cartulario de Castellote (as n. 12), doc. 9, pp. 80-81. An agreement for collaboration in war and mutual aid was also made between Santiago and San Julián de Pereiro in 1202: Colección diplomática medieval de la orden de Alcántara (1157? - 1494), ed. B. Palacios Martín, 2 vols, Madrid 2000-2003, here vol. 1, doc. 45, p. 24. In promising mutual aid against aggressors the Hospital and Santiago in 1283 excluded the Temple and Calatrava respectively, with whom they had hermandades: Libro de privilegios (as n. 6), doc. 364, pp. 586-588.

58 Delaville Le Roulx, Cartulaire (as n. 11), here vol. 2, doc. 2902, pp. 859-863; Strelhke (as n. 11), doc. 116, pp. 98-103.

59 Bullarium de Calatrava (as n. 4), pp. 683-684; Delaville Le Roulx, Cartulaire (as n. 11), here vol. 1, doc. 558, pp. 378-379; Hiestand (as n. 16), docs 27-28, pp. 237-247; Pagarolas i Sabaté, La comanda del Temple de Tortosa (as n. 16), doc. 69, pp. 239-241; Col.lecció diplomàtica de Gardeny (as n. 16), here vol. 1, doc. 332, pp. 485-487; Ferreira (as n. 16), here vol. 2, pp. 785-788; Mayer (as n. 16), here vol. 2, doc. 407, pp. 693-697.

60 See, for example, Claverie (as n. 33), here vol. 2, pp. 186-189.

61 See, for example, Lomax (as n. 15), p. 44. 


\section{SumMaRY \\ Procedures for the Settlement of Disputes between Military Orders in the Twelfth and Thirteenth Centuries}

Military orders sought not only to prevent disputes with similar foundations by agreeing regulations on subjects such as transfers between orders but also to establish long-term procedures for the settlement by arbitration of disputes, particularly about property rights. These usually provided for the naming of a certain number of arbiters drawn from the orders themselves.Yet in practice these arrangements for arbitration were commonly ignored, and ad hoc measures were usually taken to bring altercations to an end: decisions were often entrusted to external arbiters or to the pope. There were several possible reasons for this neglect of agreed procedures, including ignorance on the part of officials. Provisions for the avoidance or settlement of disputes were just one aspect of the networks which were created, either formally or informally, between military orders and which also provided for co-operation in war and mutual aid and defence against aggressors. 
